\title{
2つの孔を持つ木質有孔梁の強度算定法の提案 STRENGTH CALCULATION METHOD OF TIMBER BEAM WITH TWO HOLES
}

\author{
野口昌宏*, 中村昇** \\ Masahiro NOGUCHI and Noboru NAKAMURA
}

\begin{abstract}
Now, there are the needs of the utilization of timber structure to the non-housing buildings. It needs the several techniques without the conventional wooden structure techniques. The multi story wooden structures having long span need the technique of making large holes in the beams due to the pipe arrangement of the equipments. We, in this article, propose a manual strength calculation method of the timber with two circular holes taken into account the size effect, the hole size, the distance between the both holes, and the ratio of the bending moment and shear force as the parameters. Two failure modes was assumed, the shear failure of timber between the both holes, and the splitting fracture from the hole. From the experimental observation, the shear failure was occurred in the specimen having the short distance between the holes -less than 0.5 times of the hole diameter. And splitting fracture was occurred in the specimen having the long distance between the holes -over 0.5 times of the hole diameter. The calculation method was derived from the mechanical models based on fracture mechanics and basic beam theory. The validity of the proposed calculation method was confirmed by the experimental results whose parameters were the hole size, the size effect, and the distance between both the holes.
\end{abstract}

Keywords : Strength calculation method, Circular hole, Fracture mechanics 強度算定法, 有孔梁, 破壊力学

\section{1. はじめに}

木質構造でも、住宅の大空間化や非戸建多層木造建築物への利用 用途拡大に伴い、梁せいがおおきくなり、梁下に上下水管やダクト 等の設備配管が納まらないために、梁や小梁に貫通孔をあける場合 が想定される。木質構造では、2007 年枠組壁工法建築物設計の手引 1)やフラット 35 の枠組壁工法 ${ }^{2)}$ での仕様規定はあるが、それらのマ ニュアルには根拠や強度算定式は記されておらず、工法をこえた利 用は難しい。色々な国で孔一つをもつ有孔梁の研究が行われている 3) 12)。これらの研究は著者の既往の文献 ${ }^{12)}$ に詳細に紹介している。 筆者らはこれまでに、1 つの孔を持つ有孔梁の強度算定法を提案し ている ${ }^{12)}$ 。しかし、設備配管は、吸気 (水)、排気 (水) と二つの 配管が一組として設置される場合が多く、孔一つの強度算定法では 実用上使用できないケースが多い。また、既報の強度算定法 ${ }^{31}$ は有 限要素法の応力分布結果を参考に力学モデルを組み立てたため、大 変煩雑な算定式であり、実用に耐えられないとも考えられる。

そこで本論文では、二個の孔を有する木質有孔梁に焦点をあて、 なるべく簡易なモデル化をとおして強度算定式を提案する。

第二章では実験方法について、第三章では力学モデル化と強度算 定法の誘導について、第四章では実験結果と強度算定法の妥当性に ついて論じる。

\section{2. 実験方法}

\section{1 試験体概要}

$120 \times 30 \times 3000 \mathrm{~mm}$ のスギ製材 $\left(\right.$ 平均密度 $332 \mathrm{~kg} / \mathrm{m}^{3}$ 、平均含水率 $12.8 \%$ )、材せいが $160 \times 105 \times 4000 \mathrm{~mm}$ 、および、 $240 \times 105 \times 4000 \mathrm{~mm}$ のスギ集成材（対称異等級構成 E65-F225）を用いて図 1 に示すよう

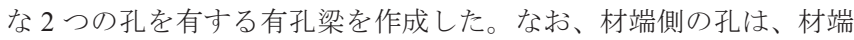
からの端あきが材せい $h$ となるように設定した。また、材中央側の 孔と加力点中心の材中央までの距離も、図 1 に示すように材せい $h$ となるように設定した。孔は材せい方向の中央に設定した。条件は 試験体の孔の大きさ、孔間隔 (心心距離)、材せいが強度に及ぼす影 響が把握できるように表 1 、表 2 に示寸ように設定した。孔の大き さや孔間隔の寸法比率が分かるように一例を図 2 に示す。

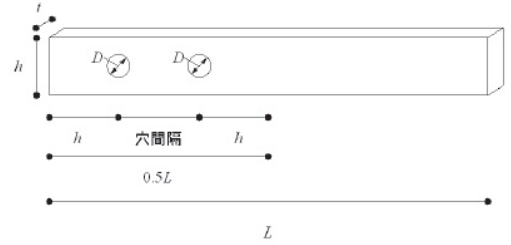

図 1 試験体の幾何学的寸法の定義
* 秋田県立大学木材高度加工研究所 流動研究員 - 農博

** 秋田県立大学木材高度加工研究所 教授・農博
Postdoctoral Fellow, Institute of Wood Technology, Akita Prefectural University, Dr. Agr. Prof., Institute of Wood Technology, Akita Prefectural University, Dr. Agr. 
表 1 材せい $120 \mathrm{~mm}$ の場合

\begin{tabular}{|c|c|c|c|c|c|}
\hline \multicolumn{2}{|c|}{} & \multicolumn{4}{|c|}{ 間隔 } \\
\cline { 3 - 6 } & $0.25 h$ & $0.5 h$ & $h$ & $1.33 h$ \\
\hline \multirow{4}{*}{ 孔径 } & $0.3 h$ & 3体 & 3体 & 3体 & 3体 \\
\cline { 2 - 6 } & $0.4 h$ & 3体 & 3体 & 3体 & 3体 \\
\cline { 2 - 6 } & $0.5 h$ & 3体 & 3体 & 3体 & 3体 \\
\cline { 2 - 6 } & $0.6 h$ & 3体 & 3体 & 3体 & 3体 \\
\hline
\end{tabular}

表 2 材せい $160 \mathrm{~mm}$ 及び $240 \mathrm{~mm}$

\begin{tabular}{|c|c|c|c|c|c|}
\hline & \multicolumn{4}{|c|}{ 間隔 } \\
\hline & & $0.25 h$ & $0.5 h$ & $h$ & $1.33 h$ \\
\hline \multirow{4}{*}{ 孔径 } & $0.3 h$ & 2体 & & & 2体 \\
\hline & $0.4 h$ & 2体 & & & 2体 \\
\hline & $0.5 h$ & 2体 & & & 2体 \\
\hline & $0.6 h$ & & & & \\
\hline
\end{tabular}

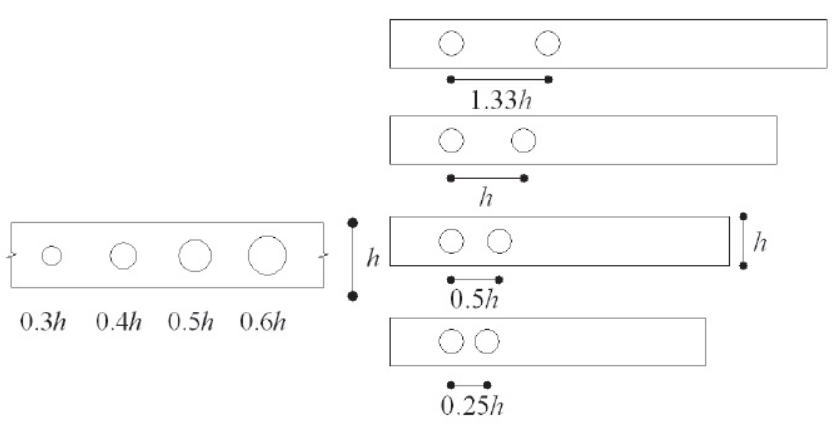

(a)孔直径

(b)孔間隔

図 2 孔および孔間隔の寸法比の例

\section{2 加カおよび計測方法}

加力は、図 3 に示すように中央載荷の 3 点曲げせん断試験とした。 加力は静的単調加力とし、破壊に至らしめた。荷重は加力点上部に ロードセルを設置して計測した。また、梁の中央たわみおよび支点 部のめり込みやガタは変位計で連続的に測定し、真の中央たわみは 支点部のめり込みやガタをキャンセルした值とした。

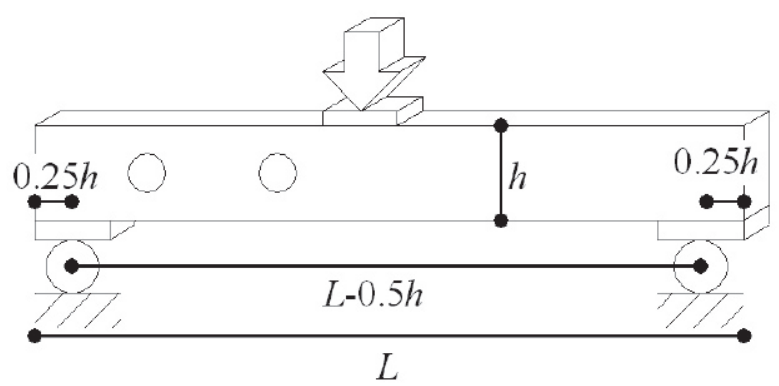

図 3 曲げせん断試験概要

\section{3. 強度算定法の誘導}

3.1 節ではモデル化の方針を、3.2 節では破壊形態と破壊の定義を、 3.3 節ではせん断破壊を、3.4 節では割裂破壊での強度算定法を導出 寸る。3.5 節で有孔梁の強度算定式をまとめて示す。

\section{1 モデル化の方針}

まず、有孔梁の孔から生じる割裂破壊の破壊面および破壊機構を 想定する。そして、梁の初等理論を用いて有孔梁をモデル化し、せ ん断力と曲げモーメントの作用下で割裂破壊面に生じるそれぞれの
応力の算定式を誘導する。また、全体を通して式が複雑になりそう な部分では、なるべく式がシンプルになるように仮定を設定した。 なお、孔の円形をそのまま扱うと、計算過程（積分時）で対数が入 ってしまうため、本論文では円形孔を適当な矩形孔に置き換えてモ デル化した。

\section{2 破壊形態と破壊の定義}

まず、実験で観察された破壊形態の分析を行う。破壊形態観察か ら、孔径や梁せい寸法による破壊形態の違いは無く、材せいに対す る孔間隔比により破壞形態が異なった。実験では、写真 1(a)に示す ような二つの孔が全く関与せず各々の孔から割れが生じた破壊形態 と、写真 1(b)に示寸ような二つの孔の間の木部がせん断破壞して、 それがトリガーとなって全体に割れが進展した破壊形態の二つが観 察された。本論文では、前者を割裂破壊、後者をせん断破壊と呼ぶ。 割裂破壊は孔間隔が梁せいの 1.0 倍および 1.33 倍と孔間隔が大きな 条件の場合に、せん断破壞は孔間隔が梁せいの 0.25 倍および 0.5 倍 と孔間隔が小さな条件の場合に観察された。

破壞形態の観察に基づき、破壊機構を図 4 に示寸ように割裂破壊 とせん断破壊の 2 つのクライテリアを想定し、それらの小さい方の 強度が有孔梁の強度と定義した。

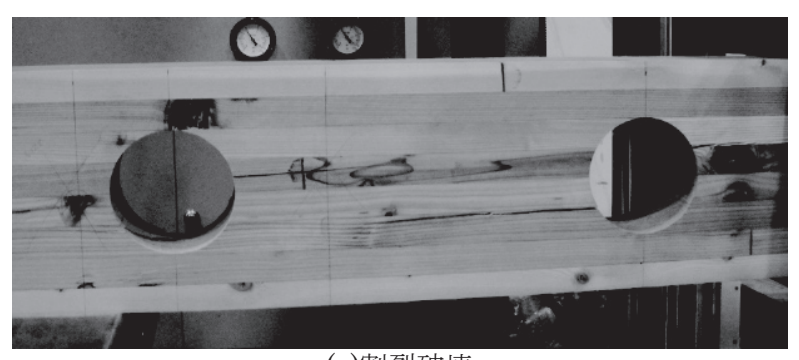

(a)割裂破壊

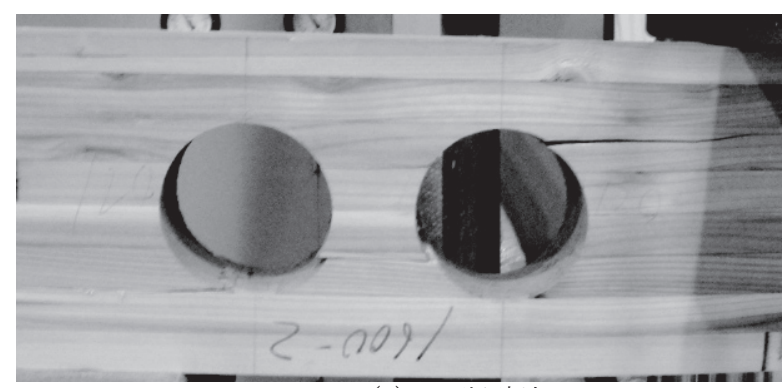

(b)せん断破壊

写真 1 破壊形態一覧

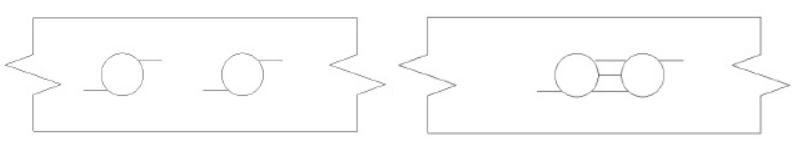

(a)割裂破壊

(b)せん断破壊

図 4 実験観察により確認できた破壊モード

\section{3 せん断破壊}

孔と孔との間の木部がせん断破壊する場合を想定してモデル化を 行う。3.3.1 節では破壊クライテリアの定義を、3.3.2 節でせん断力 を、3.3.3 節で曲げモーメントにより破壊想定面に作用するせん断応 力算定法を説明する。3.3.4 節で FEM を用いた検証を行う。 


\section{3.1 破壊クライテリア}

実験で得られた破壊形態から、図 5(a)の太実線で示す部分、また は、太点線で示寸部分にせん断破壊が観察された。この破壊形態の 違いは、試験条件の違いでは説明できなかった。せん断破壞想定面 のせん断長さが最も小さくなるように、図 5(b)に示すように孔の円 を内接円とした正方形とし、点線で示す部分をせん断破壊想定面と した。

有孔梁のせん断破壊は、梁に作用するせん断力および曲げモーメ ントにより破壊想定面に生じるせん断応力が木材のせん断強度 $\tau$ に 達した時と定義した。つまり、破壞面の長さ $s$ と材幅 $t$ との積であ るせん断破壊想定面積を用いて表現すると、

$$
\tau=\frac{Q_{a s}+Q_{a M}}{s t}
$$

と定義した。ただし、 $Q_{a s}$ は 3.3 .2 節で、 $Q_{a M}$ は 3.3 .3 節で詳細に扱 う。

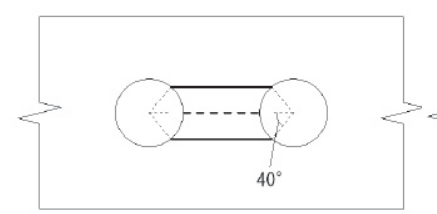

(a)実験観察からの破壞面

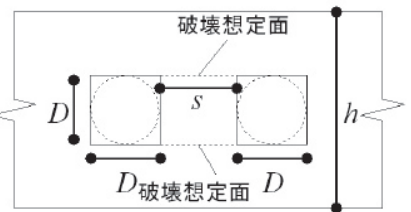

(b)孔の置換モデルと破壊想定面 図 5 せん断破壊の想定

\section{3. 2 せん断カにより破壊想定面に作用するせん断応力}

まず、図 6 に示すように孔と孔との間の木部がせん断破壊する前 の状態とせん断破壊した後の状態を想定した。梁にせん断力が作用 している場合、せん断破壊する前、および、せん断破壊した後の変 形は図 7 のよになる。また、各部に作用する応力は、それぞれ、 図 8(a)および図 8(b)になると仮定する。次に、孔と孔との間の木部 がせん断破壊した後の状態からせん断破壊する前の状態にするため に必要な条件を考える。

図 7(b)に示すせん断破壊後の状態に図 9(a)に示寸ようにブロック を挿入して、そのブロック部がせん断破壊前に負担していたである うせん断力を外力として与えると、図 8(a) と同じ応力分布になる。 しかし、ブロックに鉛直方向の偶力のみを与えると、全体としてモ 一メントも付与されるため、このモーメントを打ち消寸方向の水平 方向の偶力も与える必要がある。なお、水平方向の偶力は、図 9(b) に示すように、せん断破壊想定面に作用するせん断力 $Q_{a s}$ として与 えた。図 9(b)に示すモーメントの釣合い条件から、

$$
\frac{D Q}{h} \times S=Q_{a s} \times D
$$

が求まる。 $Q_{a s}$ について解きなおすと、せん断破壊想定面に作用寸る せん断応力度の総和（せん断力） $Q_{a s}$ は梁に作用するせん断力 $Q$ を 用いて、

$$
Q_{a s}=\frac{s}{h} Q
$$

として表現できる。

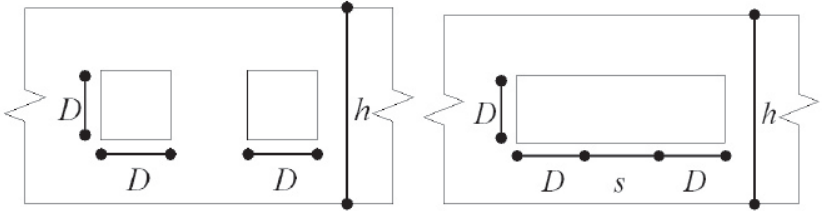

(a) せん断破壊前

（b）せん断破壊後

図 6 せん断力によるせん断破壊前後の想定モデル

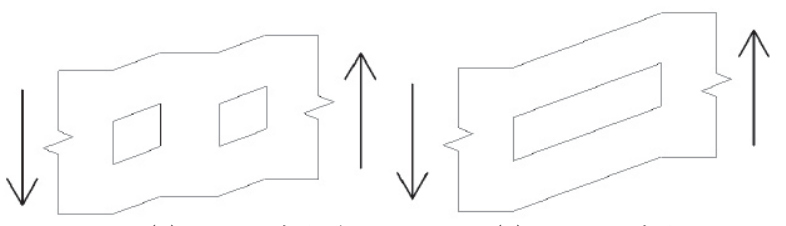

(a)せん断破壊前

（b）せん断破壊後

図 7 せん断力によるせん断破壊前後のせん断変形想定図

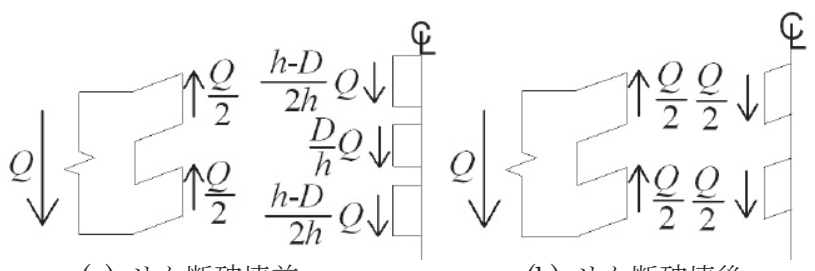

(a) せん断破壊前

(b) せん断破壊後

図 8 各部位に作用するせん断力想定図

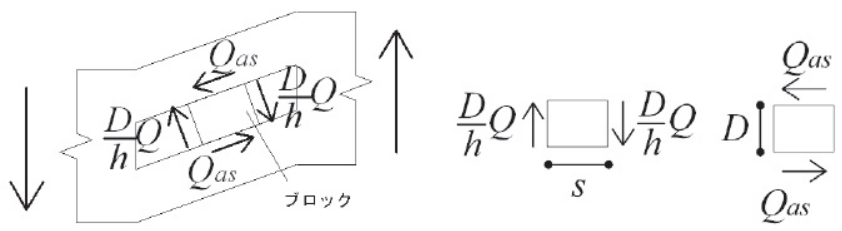

(a)必要な仮想外力 （b）ブロックに作用する鉛直・水平方向偶力 図 9 せん断力によるせん断破壊前後を結びつけるためのモデル

\section{3. 3 曲げモーメントにより破壊想定面に作用するせん断応力}

曲げモーメントについても、3.3.2 節と同様な方法でモデル化する。 まず、図 10 に示すように孔と孔との間の木部がせん断破壊する前の 状態とせん断破壊した後の状態を想定した。梁に曲げモーメントが 作用している場合、平面保持が成立すると仮定すると、せん断破壊 寸る前、および、せん断破壊した後の面 AA'の曲げ応力度分布は、 それぞれ、図 11 に示寸ようになる。次に、孔と孔との間の木部がせ ん断破壊した後の状態からせん断破壊する前の状態にするために必 要な条件を考える。そうすると、(1)せん断破壊前にブロック（孔と 孔の間の木部) が負担していたはずのモーメント $M_{t}$ をブロックに外 力としてくわえる。次に、(2)せん断破壊後の曲げモーメントから、 孔と孔の間の木部が負担する曲げモーメントを引く必要がある。こ の 2 つのことを同時に満たすために、図 12 に示すようにせん断破壊 後の状態と孔と孔との間の木部（図 12 のブロック）にそれぞれ等価 なせん断力 $Q_{a M}$ を加えた。

まず、図 12(b)のブロックに着目する。孔部が負担していると考え られる曲げモーメント $M_{t}$ は梁せい $h$ の断面二次モーメント $I$ と孔部 の断面二次モーメント $I_{\text {hole }}$ の比から

$$
M_{t}=\frac{I_{\text {hole }}}{I} \times M=\frac{D^{3}}{h^{3}} M
$$

として表現できる。図 12(b)に示すように、付加モーメント $M_{t}$ はせ 
ん断破壊想定面に作用する等価せん断力せん断力 $Q_{a M}$ を用いて表現 すると、

$$
Q_{a M}=\frac{M_{t}}{D}=\frac{D^{2}}{h^{3}} M
$$

となり、せん断破壊想定面に作用するせん断力 $Q_{a M}$ が表現できる。

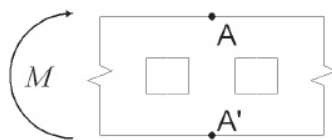

(a) せん断破壊前
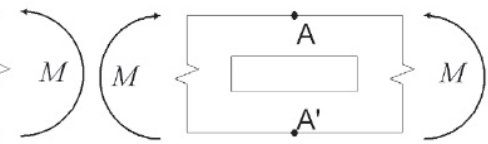

（b）せん断破壊後
図 10 曲げモーメントによるせん断破壞想定モデル

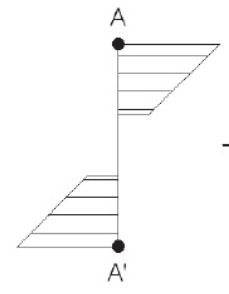

せん断破壊後

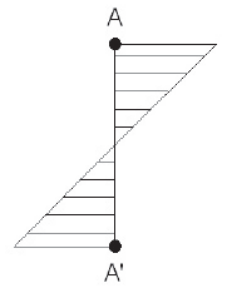

せん断破壊前

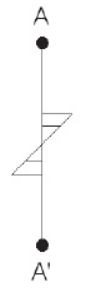

必要な仮想モーメント

図 11 面 $\mathrm{AA}^{\prime}$ の曲げ応力度分布

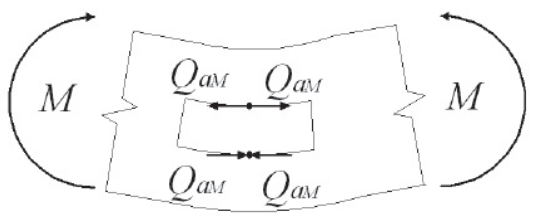

(a) せん断破壊後の状態に必要な外力

(b) ブロックに必要な外力

\section{3. 4 モデルのせん断破壊部に作用する応力のFEM比較による妥当 性の検討}

一般的に、梁のせん断応力度は、材せいの中央が最大の放物線状 の分布になる。これは欠点のない梁の場合の話であり、久点のある 梁の場合はその周辺では欠点によって応力が乱れて放物線状分布に はならない。例えば、図 8(a)の状態を考えると、左端に作用するせ ん断力は、孔がある部分では孔の上側と下側に流れるはずである。 そして、それらのせん断力がさらに右に流れる場合、孔の上側と下 側のせん断力は再び一般的な梁理論のような理想的なせん断応力分 布になる。しかし、理想的なせん断応力分布になるのは、応力が乱 れたところから十分距離がはなれたところの話である。等方性体の ような場合は、45 度に応力拡散すると考えられるため、梁せい分の 距離が離れると理想的なせん断応力度分布になると考えられる。異 方性体の木質材料では、既往の研究 FEM 解析 ${ }^{12)}$ より、木質有孔梁 の場合、孔周辺からの応力拡散角度は約 18 度との報告がある。この ことから考えると、理想的なせん断応力度分布になるのは、少なく とも梁せいの 2〜3 倍以上の距離が必要と考えられる。この事から、 今回の実験の範囲では、孔と孔との間の木部の平均的な材軸方向の せん断応力度分布は、等分布と放物線状分布の間の状態と考えられ る。3.3.2 節では、材せい方向のせん断応力度分布を等分布としてモ デル化しているため、その工学的妥当性を検討する必要がある。

せん断破壊部に作用する応力度の総和（せん断力）を FEM 線形
応力解析の算定值（FEM 值）とモデルでの計算値の比較を行い、材 せい方向のせん断応力度分布を等分布と仮定した力学的モデルの妥 当性を検討した。有限要素法を用いた解析は、2D の平面応力状態の 有限要素モデルを作成し、線形応力解析を行った。図 13 に検討モデ ルの一例を示す。なお、全ての実験条件を対象とした。表 3 に材料 定数を示す。なお、材料定数は、木材工業ハンドブック ${ }^{4)}$ 参考に 決めた。荷重および境界条件は、実験の条件を再現できるように設 定した。荷重は鋼製の鉄板部分に等分布荷重を与えた。木材および 鉄板は 4 節点平面要素で表現した。要素分割は、孔の円周を実寸 $1 \mathrm{~mm}$ ごとに、他の部分も実寸 $1 \mathrm{~mm}$ ごとに節点を設けた。計算值は存在 応力から式(3)と式(5)で算出したせん断力の和を用いた。図 14 に と孔にはさまれるせん断破壊想定面に作用しているせん断力（せん 断応力度の総和）について、FEM 值と計算值の比較を示す。FEM 值と計算值は比例関係で、FEM 值は計算值の 1 倍から 1.3 倍の間に 収まっていることが確認できる。孔間隔が小さい場合は FEM 值は 計算值の 1 倍に近く、孔間隔が大きくなるにつれて FEM 值は計算 值の 1.3 倍に近づく傾向であった。FEM 值が計算值の 1 倍の場合は 材せい方向のせん断応力度分布は等分布が妥当、一方、FEM 值が計 算値の 1.5 倍の場合は材せい方向のせん断応力度分布は放物線分布 が妥当と考えられる。これらの事から、本研究で扱っている条件内 では、材せい方向のせん断応力度分布は等分布と放物線状分布との 間の状態と判断できる。孔からの距離が異なれば材軸方向のせん断 応力度分布が変化すること、孔の応力集中により応力が乱れること、 条件が多いこと、及び、FEM の応力分布の詳細から傾向をルール化 することが困難であった。そのため、本論文では、せん断破壊は孔 間隔が小さい場合に観察された破壊形態であること、および、孔間 隔が小さい場合に FEM 值は計算值の 1 倍に近いことを根拠に、材 せい方向のせん断応力度分布を等分布と仮定した力学的モデルは工 学的に概衩妥当と判断した。なお、せん断応力度分布の普遍的なル ール化は今後の課題である。

表 3 材料定数 ${ }^{13)}$

\begin{tabular}{ccc} 
& & \\
\hline 記号 & \multicolumn{2}{c}{ 值 } \\
\hline$E_{x}$ & 6500 & $\mathrm{~N} / \mathrm{mm}^{2}$ \\
$E_{y}$ & 260 & $\mathrm{~N} / \mathrm{mm}^{2}$ \\
$G_{x y}$ & 433 & $\mathrm{~N} / \mathrm{mm}^{2}$ \\
$\mu_{x y}$ & 0.49 & \\
\hline
\end{tabular}

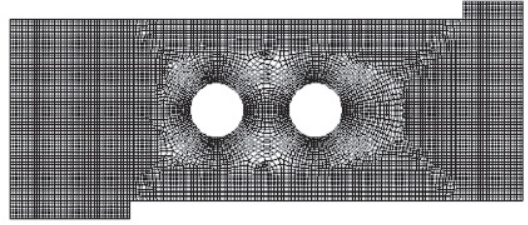

図 13 有限要素モデル

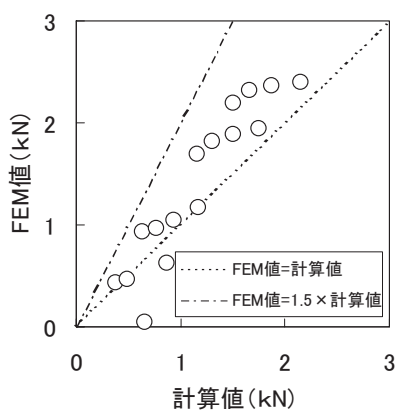

図 14 破壊想定面に作用するせん断力の FEM 值と計算值の関係

\section{4 割裂破壊}


ここでは、孔と孔とが無関係に割裂破壊が生じるケースを対象に 強度算定式を誘導する。

\section{4.1 モデル化流れと割裂破壊の定義}

まず、割裂で材が 2 つ分離する破壊面を想定し、クラックが面 積 $\Delta A$ 進展するに伴うポテンシャルエネルギーの損失 $\Delta W$ を梁の初 等理論を用いて表す。

次に割裂破壊位置について検討する。実験では、有孔梁に曲げモ 一メントのみが作用している時は図15のAと Bの位置付近に割れが 生じ、一方、せん断力が卓越して作用している時は図15のAとCの位 置付近に割れが生じて破壞した。本論文で対象とする曲げモーメン トとせん断力の複合応力が作用する場合は、各々の共通部分である Aの位置に割れが生じる時点で破壊と定義した。

また、既報 ${ }^{12}$ から、純曲げの場合は36度付近、純せん断の場合は 40度付近に応力集中寸るとの報告を参考に、割れ発生位置を図16に 示すように孔中心から 40 度の角度をもった位置とした。有孔梁の場 合は、せん断力の方が卓越する場合が多いと考え、せん断力が作用 する場合の応力集中部を破壞想定位置とした。また、誘導の簡易化 のため、図17(a)に示寸有孔梁を、図17(b)に示寸ようにモデル化した。
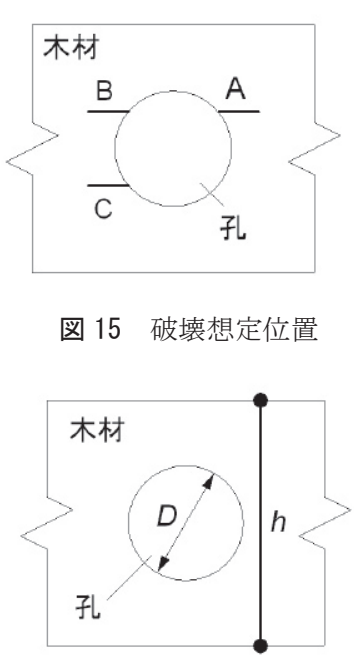

(a)幾何学的記号
図 15 破壞想定位置

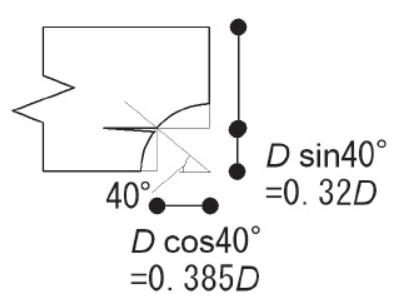

図 16 割れ発生位置の想定

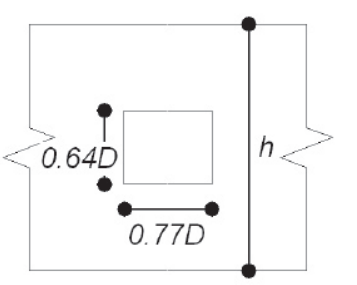

（b）想定モデル
図 17 孔の簡易モデル化

既報の実験データ ${ }^{3)}$ から、木質有孔梁におけるせん断力と曲げモ ーメント複合応力の破壊構成則は、おおむね二乗則があてはまった ため、本報でもこれに順じ、

$$
\left(\frac{M}{M_{m}}\right)^{2}+\left(\frac{Q}{Q_{m}}\right)^{2}=1
$$

とした。なお、 $M$ : 存在曲げモーメント、 $M_{m}$ : 純曲げの場合の破壞 モーメント、 $Q$ : 存在せん断力、 $Q_{m}$ : 純せん断の場合の破壊せん断 力を表す。

木材の割裂破壊は、Hiberhort 等の結合力モデルで表現した。材料 定数として破壊エネルギー $G_{f}$ を用いた。つまり、破壊クライテリア は

$$
G_{f}=\frac{\Delta W}{\Delta A}
$$

を用いた。

\subsection{2 せん断カによる割裂破壊強度}

図 18(a)に示寸ように有孔梁の孔の中心を通る材せい方向と材長 方向の線で 4 分割に切断し、そのうちの $1 / 4$ 部分に焦点をあてて梁 の基礎理論を用いてモデル化した。図 18(c)に示すように $\Delta x$ クラッ ク長が進展した場合、梁のクラックより下にある部分（図 18(c)の領 域 A）には力が流れずに、梁の剛性には寄与しないと考えた。そう すると、クラック長さが $\Delta x$ 進展した場合、図 18(d)に示すように切 欠き長さが $\Delta x$ だけ増加した梁として扱うことができる。

ここで、本論文ではなるべく簡易な耐力算定式誘導を目的にして いるため、梁の変形計算の簡易化を行う。図 19 に、図 18(b)に示す 片もち梁モデルで計算した曲げ変形とせん断変形比に対する孔径と 材せい比の関係を示す。変形計算は、図 18(b)に示す片もち梁モデル で梁先端のたわみをもとめた。梁せい $120 \mathrm{~mm}$ の場合を想定し、幾 何学的寸法は図 16 を用いた。孔径と材せい比が 0.3 の場合は曲げ変 形はせん断変形の 0.018 倍、孔径と材せい比が 0.4 の場合は曲げ変 形はせん断変形の 0.085 倍、孔径と材せい比が 0.45 の場合は曲げ変 形はせん断変形の 0.25 倍となる。孔径と材せい比は、鉄筋コンクリ 一ト造では 0.3 であること、なるべく簡易な耐力算定式誘導を目的 にしていること、及び同様のモデル化では曲げ変形の項を最終的に 省略している報告が多いこと ${ }^{14) ~ 18)}$ 等も考慮し、本論文では、図 18(b) と(d)に示す片もち梁モデルのたわみ量は梁のせん断変形のみで計 算した。
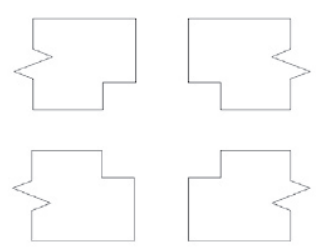

(a) 4 分割

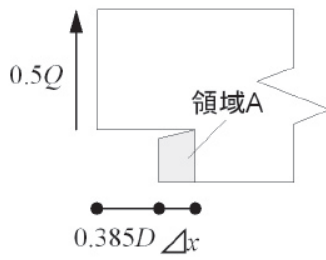

(c) 割れ発生後

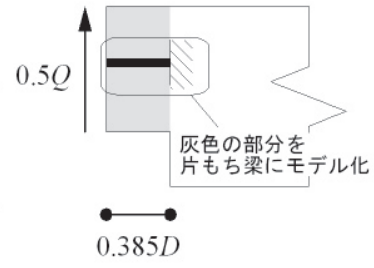

(b)割れ発生前

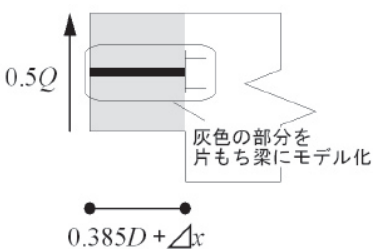

（d）割れ発生後等価モデル
図 18 モデル化の想定と割裂と切り久きの扱い

図 15 に示す A と C の位置に同時に割れが入ると仮定した。せん断 力が一定 $Q$ 、矩形断面、切欠き部分のある部分とない部分における それぞれのせん断たわみ量の和をとって計算すると、クラック長さ が $x$ 時点での加力点でのたわみ量の増分 $\Delta \delta$ は

$$
\Delta \delta=\frac{1.2 \Delta x Q}{G b h}\left(\frac{1}{\alpha}-1\right)
$$

で表現できる。ただし、 $b$ は材幅、 $h$ は材せい、 $G$ はせん断弾性係数、 $\alpha=(0.5 h-0.32 D) / 0.5 h$ を表す。ポテンシャルエネルギー増分 $\Delta W$ は 


$$
\Delta W=\frac{Q \Delta \delta}{2}=\frac{M \Delta \theta}{2}
$$

で表現できる。式（7）、式（8）、および、式（9）を連立すると、せ ん断力による割裂破壊の強度算定式 $Q_{m}$ は

$$
Q_{m}=b \sqrt{\frac{G G_{f} \alpha h}{0.6(1-\alpha)}}
$$

として導出できる。

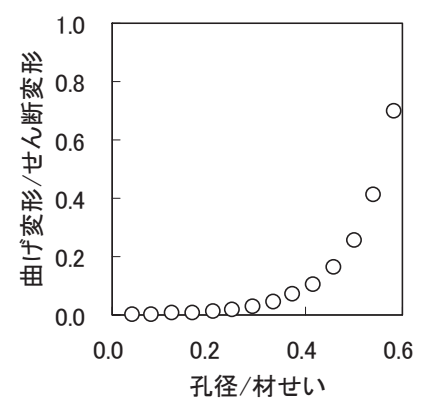

図 19 曲げ変形とせん断変形比と孔径と材せい比の関係

\subsection{3曲げモーメントによる割裂破壊強度}

図 20 に示すように、孔の中心を通る鉛直線で切断した片方に焦点 をあて、モデル化する。梁に曲げモーメントのみが作用していると 考える。そうすると、図 20 の領域 $\mathrm{A}$ と領域 C の曲げ変形はクラッ クが入る前と入った後では変化がない。一方、図 20(b)に示すように 孔の端から距離 $\Delta x$ までの領域（領域 $\mathrm{B}$ ）では、クラックが入る前 は曲げモーメントに対する有効な材せいは $h$ であるから、曲げモー メントによる撓み角 $\theta$ は

$$
\theta=\frac{M}{E I} \Delta x
$$

で表現できる。ただし、 $I=b h^{3} / 12 、 E$ はヤング係数。

次に、クラック入った後を考える。図20(b)に示すような割れが入 るためには割れの上部と割れの下部の間に鉛直方向の変位が発生し ているはずであり、平面保持の仮定の前提が完全に崩れる。最も安 全側の評価として、割れの上部に力が流れず、曲げモーメントに対 する有効な材せいは割れの下側のみとした。そうすると、割れが生 じた後の領域 B での曲げモーメントによる撓み角 $\theta$ は、

$$
\theta=\frac{M}{E I_{h}} \Delta x
$$

となる。ただし、 $I_{h}=b(0.5 h+0.32 D)^{3} / 12$ 。こで、 $\gamma h=0.5 h+0.32 D$ と置き換え、割れ進展後の撓み角から割れ進展前の撓み角を差し引 いた差分 $\Delta \theta$ は

$$
\Delta \theta=\frac{M}{E I \gamma^{3}} \Delta x-\frac{M}{E I} \Delta x=\frac{M}{E I} \Delta x\left(\frac{1}{\gamma^{3}}-1\right)
$$

となる。式（7）、式（9）、式（13）を連立すると、純曲げの場合の 破壞モーメント $M_{m}$ の算定式が

$$
M_{m}=\sqrt{\frac{2 E I G_{f} b}{\left(\frac{1}{\gamma^{3}}-1\right)}}
$$

として導出できる。ただし、 $I=b h^{3} / 12 、 \gamma=(0.5 h+0.32 D) / h$

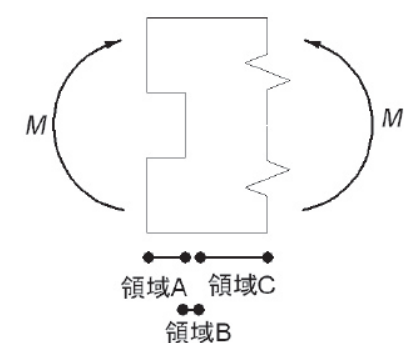

(a)割れ進展前

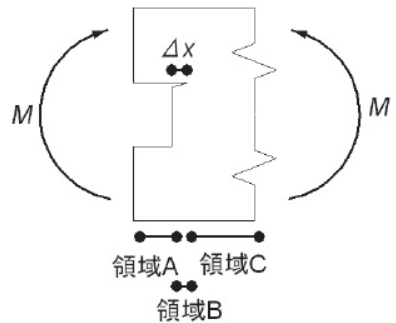

(b) 割れ進展後
図 20 曲げモーメントによる割裂破壞想定モデル

\section{5 有孔梁の強度算定法}

存在応力が式 (15)、および式(16)を満たす事を確認する。

$$
\begin{gathered}
\tau>\frac{Q_{a s}+Q_{a M}}{s t} \ldots(15) \\
\left(\frac{M}{M_{m}}\right)^{2}+\left(\frac{Q}{Q_{m}}\right)^{2}<1 \ldots(16)
\end{gathered}
$$

ただし、 $Q_{a s}=\frac{s}{h} Q \quad Q_{a M}=\frac{M_{t}}{D}=\frac{D^{2}}{h^{3}} M$

$$
Q_{m}=b \sqrt{\frac{G G_{c} \alpha h}{0.6(1-\alpha)}} \quad M_{m}=\sqrt{\frac{2 b E I G_{f}}{\left(\frac{1}{\gamma^{3}}-1\right)}} \quad Q=\frac{P}{2}, \quad M=\frac{P}{2} X
$$

ただし、 $I=b h^{3} / 12 、 \alpha=(0.5 h-0.32 D) / h 、 \gamma=(0.5 h+0.32 D) / h$ なお、 $M$ : 存在曲げモーメント、 $M_{m}$ : 純曲げの場合の破壞モーメン 卜、 $Q$ : 存在せん断力、 $Q_{m}$ : 純せん断の場合の破壊せん断力、 $D:$ 孔径、 $s$ : 破壊面の長さ、 $G_{f}$ : 破壊エネルギー、 $h:$ 梁せい、 $b$ : 梁幅、 $E$ : 弾性係数、 $G$ : せん断弾性係数、 $\tau$ : せん断強度、 $P$ : 梁に作用 する荷重、 $X$ : 梁端部からの距離を表す。

\section{6 計算に用いた材料定数}

ヤング係数 $E$ は $6.5 \mathrm{GPa}$ 、せん断弾性係数は日本建築学会木質構 造設計規準に準じて $E / 15$ を用いた。破壊エネルギー $\left(G_{f}\right)$ は $G_{f}=$

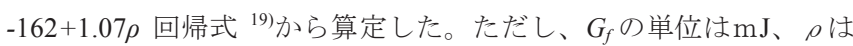

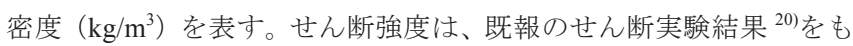
とに $4 \mathrm{MPa}$ を用いた。

\section{4. 実験結果と算定値の比較}

\section{1 孔直径の影響}

図 21 に梁せいが $120 \mathrm{~mm}$ の場合の孔間隔ごとの孔径と有孔梁の実 験結果と算定值の関係を示す。まず、実験結果について検討する。 全体として、孔径が大きくなるに伴いせん断耐力が小さくなってい ることが確認できる。しかし、孔間隔が $120 \mathrm{~mm}$ の条件では、孔径 が $50 \mathrm{~mm}$ までは孔間隔が小さくなるに伴いせん断耐力が小さくなっ ているが、孔径が $50 \mathrm{~mm}$ 以上ではせん断耐力の減少割合が小さくな っている。しかし、孔間隔が $180 \mathrm{~mm}$ の場合でも孔径が大きくなる に伴いせん断耐力が小さくなっていること、および、材せいが $120 \mathrm{~mm}$ の場合はスギ製材を用いていることなどを考えると、孔径が $50 \mathrm{~mm}$ 以上ではせん断耐力の減少割合が小さくなっているのは、材 のばらつきなどの影響とも考えられるが、詳細は今後の課題である。 算定式で計算した值は、概社実験值の安全側の評価を示すことが確 認できる。このことから、提案算定式は孔径の影響をおおむ称良く 
表現できており、妥当であると判断できる。

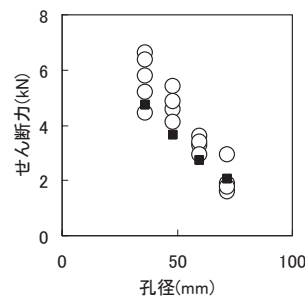

(a)孔間隔 $30 \mathrm{~mm}$

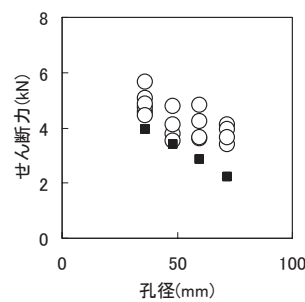

(c)孔間隔 $120 \mathrm{~mm}$ 図 21 孔直径の影響（材せい $120 \mathrm{~mm}$ ) ただし、○：実験結果、

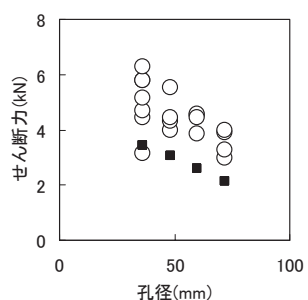

(d)孔間隔 $180 \mathrm{~mm}$

\section{2 孔間隔の影響}

図 22 に径ごとの孔間隔と有孔梁のせん断耐力の関係を示す。ま ず、実験結果について検討する。孔径が $36 \mathrm{~mm}$ および $48 \mathrm{~mm}$ の場合 は、孔間隔によらずせん断力はほぼ一定であることが確認できる。 孔径が $60 \mathrm{~mm}$ および $72 \mathrm{~mm}$ の場合は、孔間隔 $30 \mathrm{~mm} 、 60 \mathrm{~mm}$ ではほ ぼ一定のせん断耐力を示したが、孔間隔 $120 \mathrm{~mm} 、 180 \mathrm{~mm}$ では、孔 間隔 $30 \mathrm{~mm}$ のせん断耐力と比べて平均值で約 1.4 倍および 1.7 倍の せん断耐力を示した。これは、孔間隔が $30 \mathrm{~mm}$ および $60 \mathrm{~mm}$ の場合 は、孔と孔との間でせん断破壊が生じたのに対して、孔間隔が $120 \mathrm{~mm}$ および $180 \mathrm{~mm}$ の場合は、孔と孔が無関係に割裂破壊が生じ たことが原因と考えられる。

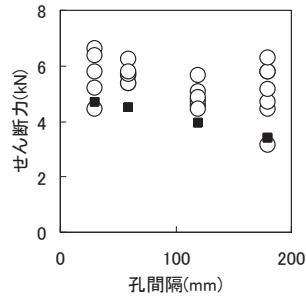

(a)孔径 $36 \mathrm{~mm}$

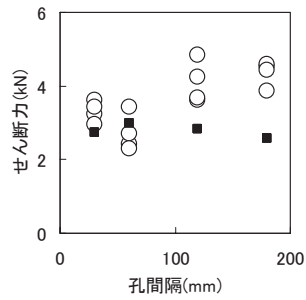

(c)孔径 $60 \mathrm{~mm}$

図 22 孔間隔の影響（材せい $120 \mathrm{~mm}$ ) ただし、○：実験結果、

$$
\text { 口 }
$$

算定值

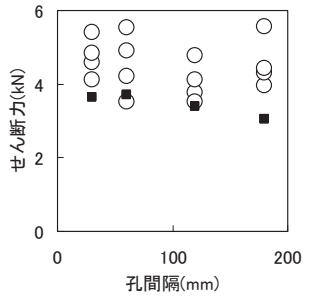

(b)孔径 $48 \mathrm{~mm}$

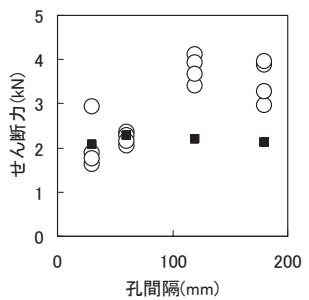

(d) 孔径 $72 \mathrm{~mm}$
孔間隔が $36 \mathrm{~mm} 、 48 \mathrm{~mm}$ と小さな場合には、両孔間にせん断破壊
が生じても孔が小さいために耐力があまり低下せず、その後の孔か ら割裂破壊で最大せん断耐力が決まったものと考えられる。一方、 孔径が大きな場合は、両孔間にせん断破壞が生じて一気に有孔梁が 崩壊したために、孔間隔が小さい場合に、小さなせん断耐力となっ たものと考えられる。算定式で計算した值は、おおむ称実験值をお さえていることが確認できる。孔間隔が孔間隔 $60 \mathrm{~mm}$ 以上では割裂 破壊で算定強度が決まったが、孔間隔が大きくなるにつれてせん断 力が小さくなっているのは、曲げモーメントが大きくなったためで ある。この事から、提案算定式は孔間隔の影響をおおむね表現でき ており、妥当であると判断できる。ただし、算定值は、孔間隔 $30 \mathrm{~mm}$ の場合にせん断破壊の算定強度できまり、孔間隔 $60 \mathrm{~mm}$ 以上では割 裂破壊で算定強度で決まったため、精度向上が課題として残る。

\section{3 寸法効果}

図 23 に材せいに対する孔径および孔間隔の比率を同じくした場 合の、材せいとせん断強度（平均せん断応力度）の関係を示す。ま ず、実験結果について検討する。全ての条件で、材せいが大きくな るにつれてせん断耐力が小さくなっていることが確認できる。この 事から、有孔梁には大きな寸法効果があると考えられる。また、全 ての条件で、せん断耐力を公称断面で除したせん断応力度は、基準 強度（スギ製材：1.8MPa、スギ集成材：3.9MPa）を下回っているこ とが確認できる。つまり、梁に梁せいの 0.3 倍以上の貫通孔を設け る際は、適切な補強をするか、有孔梁のせん断耐力を算定して使う かのどちらかの方法が必要と考えられる。
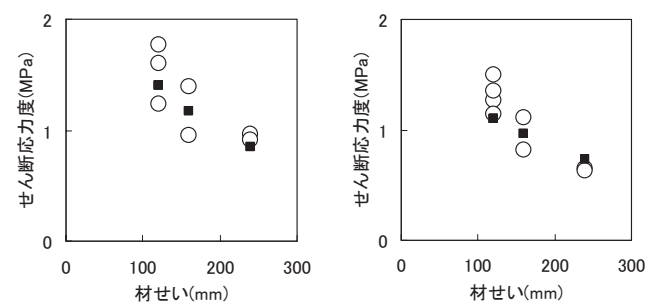

(a) 孔径 $0.3 h$ 、孔間隔 $0.25 h$ (b) 孔径 $0.4 h$ 、孔間隔 $0.25 h$
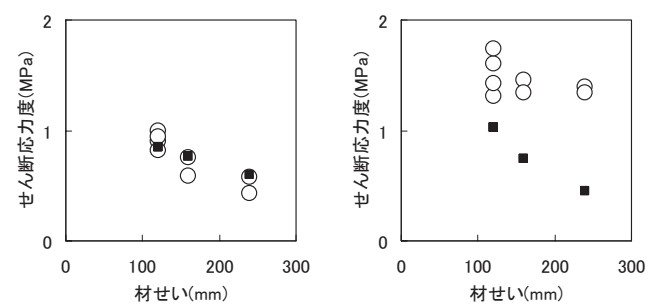

(c) 孔径 $0.5 h$ 、孔間隔 $0.25 h(\mathrm{~d})$ 孔径 $0.3 h$ 、孔間隔 $1.33 h$
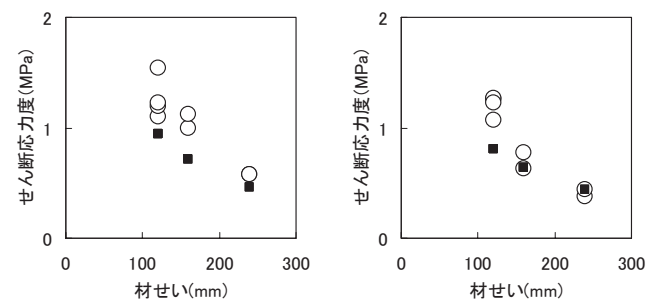

(e) 孔径 $0.4 h$ 、孔間隔 $1.33 \mathrm{~h}(\mathrm{f})$ 孔径 $0.5 h$ 、孔間隔 $1.33 h$ 図 23 寸法効果

ただし、○：実験結果、ロ : 算定値 
算定式より計算された值は、材せいに伴うせん断耐力の変化の影 響を概ね表現できていることが確認できる。ただし、図23(d)に示す 孔径 $0.3 h$ 、孔間隔 $1.33 h$ の場合は、過度の完全側の評価になること が分かった。無補強の有孔梁は、RC 造では材せいの 0.3 倍まで、 $\mathrm{S}$ 造では材せいの 0.5 倍まで許容されている。提案算定式を用いる場 合、 $\mathrm{RC}$ 造と同等の材せいの 0.3 倍までとすれば、安全側に評価でき ると考えられる。S 造と同様に材せいの 0.5 倍まで許容すると考え ると、大きな材せいでの実験結果を収集して適切な安全率の設定が 必要と考えられる。木質有孔梁の実験データは、あまり報告されて いないため、大きな材せいの実験データの収集が今後の課題と考え られる。

\section{4 強度算定式の推定精度}

図 24 に全ての実験データを用いた実験值と計算值比較を示す。せ 几断応力度、および、せん断力どちらを用いた場合でも、大きな傾 向としては計算值はおおむ称安全側の評価をすることがが確認でき る。ただし、4.3節でも述べたが孔径 $0.3 h$ 、孔間隔 $1.33 h$ の場合に過 度の安全側評価になるため、更なる推定精度向上や実務利用には、 実験データの収集が必要である。また、およびが実用的な設計式確 立のためには、適切な安全率の設定が必要と考えられる。

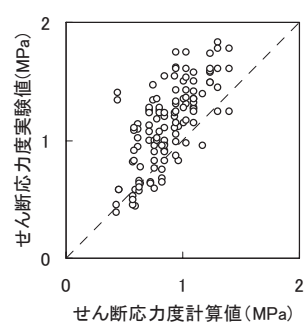

(a)せん断応力度

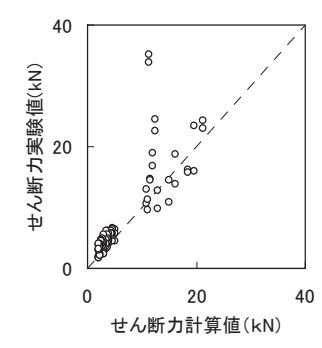

(b)せん断力
図 24 破壊荷重の実験值と計算值比較

\section{5. まとめ}

2 つの孔を持つ木質有孔梁を対象として、力学モデル化および実 験の 2 つの手法を用いて有孔梁の強度性能について検討し、以下の 結果を得た。

・有孔梁の強度算定法を以下の式で提案した。 存在応力が下式を共に満たす事を確認する。

$$
\begin{gathered}
\tau>\frac{Q_{a s}+Q_{a M}}{s t} \\
\left(\frac{M}{M_{m}}\right)^{2}+\left(\frac{Q}{Q_{m}}\right)^{2}<1
\end{gathered}
$$$$
\text { ただし、 } Q_{a s}=\frac{s}{h} Q \quad Q_{a M}=\frac{M_{t}}{D}=\frac{D^{2}}{h^{3}} M
$$

$$
Q_{m}=b \sqrt{\frac{G G_{c} \alpha h}{0.6(1-\alpha)}} \quad M_{m}=\sqrt{\frac{2 b E I G_{c}}{\left(\frac{1}{\gamma^{3}}-1\right)}}
$$

$I=b h^{3} / 12 、 \alpha=(0.5 h-0.32 D) / h 、 \gamma=(0.5 h+0.32 D) / h$

なお、 $M$ : 存在曲げモーメント、 $M_{m}$ : 純曲げの場合の破壊モーメ ント、 $Q$ : 存在せん断力、 $Q_{m}$ : 純せん断の場合の破壊せん断力、 $D$ : 孔径、 $s$ : 破壊面の長さ、 $G_{f}$ : 破壊エネルギー、 $h$ : 梁せい、 $b$ : 梁幅、
$E$ : 弾性係数、 $G$ : せん断弾性係数、 $\tau$ ：せん断強度を表す。 - 実験值との比較により、提案算定式は孔径の大きさ、孔間隔、お よび寸法効果を良い精度で推定できる事がわかった。

・全ての条件で、せん断耐力を公称断面で除したせん断応力度は、 基準強度（スギ製材：1.8MPa、スギ集成材：3.9MPa）を下回ってい ることが確認できた。つまり、梁に梁せいの 0.3 倍以上の貫通孔を 設ける際は、適切な補強をするか、有孔梁のもつせん断耐力を推定 して使うかのどちらかの方法が必要と考えられる。

・危険側の評価になる場合もあり、実験データの収集および適切な 安全率の設定が実用的な設計式確立のために必要と考えられる。

・木質有孔梁の実験データは、あまり報告されていないため、大き な材せいの実験データの収集が今後の課題と考えられる。

\section{参考文献}

1) 日本ツーバイフォー建築協会: 枠組壁工法建築物設計の手引 2007 年, 日本ツ ーバイフォー建築協会, 2007

2）住宅金融普及協会：枠組み壁工法フラット 35, 住宅金融支援機構，2007

3) Johannesson, B. : Design problems for glulam beams with holes, $\mathrm{PhD}$ thesis Dep. of Structural Engineering, Chalmers University of Technology, Göteborg, Sweden, 1983

4) Johannesson, B. : Holes in plywood beams and glued laminated timber beams. Stress concentration and crack loads, Publ. S.77:4, Chalmers University of Technology, Göteborg, Sweden, 1983

5) H. Kolb 他 : Verstärkung von durchbrochenen Brettschichtbindern, Research Report 14-34810, FMPA, Stuttgart, Germany, 1985.

6) Gustafsson, P. J 他 : Timber fracture. mechanics models for strength analysis of beams with a hole or a notch, RILEM Technical Report, Lund University, Sweden, 2000

7）軽部正彦他：円形孔を有寸る集成材の耐力, 日本建築学会大会学術講演梗 概集 C-1，構造 III，pp.225-226，2000

8) S Aicher L Höfflin : Glulam Beams with Round Holes - a Comparison of Different Design Approaches vs Test Data, Proc. CIB W18 35-12-1, 2002

9) L Höfflin, S Aicher : Weibull Based Design of Round Holes in Glulam, Proc. CIB W18 36-12-2, 2003

10) Aicher S., Hofflin L. : Load capacity and design of glulam beams with round holes - Safety relevant modifications of design methods according to Eurocode 5 and DIN 1052, MPA Otto-Graf-Institute, University of Stuttgart, 2005

11）辻本直子等: 有孔集成材梁の耐力評価と補強方法に関する研究 その 1 その 4, 日本建築学会大会学術講演梗概集 C-1, 構造 III, pp.19-22， 2006 pp.17-20, 2007

12）野口昌宏他：せん断及び曲げモーメント複合応力下の木質有孔梁の強度 算定式，日本建築学会構造系論文集 $74 ， 640$ 号, pp. 1121-1129，2009.06

13）森林総合研究所：木材工業ハンドブック，丸善, 2004

14) van der Put 他: Evaluation of perpendicular to grain failure of beams caused by concentrated loads of joints, Proc. of CIB-W18 Paper 33-7-7, 2000

15) P J Gustafsson : A Study of Strength of Notched Beams, Proc. of CIB-W18 Paper, 21-10-1, 1988

16) J. L. Jensen: Splitting strength of beams loaded perpendicular to grain by dowel joints, Vol. 51, 5, pp.480-485, 2005

17）野口昌宏他：材端に設置する繊維直角方向負荷を受ける単体木質ボルト 接合の強度算定法の提案、日本建築学会構造系論文集，74, 640 号, pp.1099-1105, 2009.06

18）野口昌宏他：木質鋼板単体ボルト接合の繊維方向荷重に対する強度算定 法の提案，日本建築学会構造系論文集，74，638 号，pp.681-690，2009.04 19)S.Thelandersson edited : Timber Engineering, John Wiley and Sons LTD, England, p. 115, 2003

20)野口昌宏: 端抜けせん断について, 日本木材学会大会研究発表要旨集, CDROM 収容，2010.03

（2010年 5 月10日原稿受理，2011年 1 月31日採用決定） 